\title{
A Review on Effect of Para-nonylphenol on Male Reproductive System
}

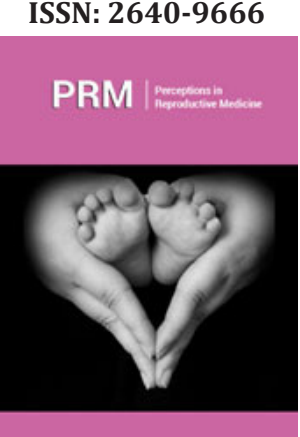

*Corresponding author: Malmir M, Sina Specialty and Multispecialty Hospital, Rastak Infertility Center, Iran

Submission: 留 February 27, 2020

Published: 盏 March 05, 2020

Volume 3 - Issue 5

How to cite this article: Malmir M, Fara T, Ghafarizadeh AA. A Review on Effect of Para-nonylphenol on Male Reproductive System. Perception in Reproductive Medicine.3(5). PRM.000572.2020.

DOI: $10.31031 /$ PRM.2020.03.000572

Copyright@ Malmir M, This article is distributed under the terms of the Creative Commons Attribution 4.0 International License, which permits unrestricted use and redistribution provided that the original author and source are credited.

\author{
Malmir $\mathrm{M}^{1 *}$, Farai $\mathrm{T}^{2}$ and Ghafarizadeh $\mathrm{AA}^{3}$ \\ ${ }^{1}$ Department of Midwifery, Tuyserkan Branch, Islamic Azad University, Tuyserkan, Iran \\ ${ }^{2}$ Sina Specialty and Multispecialty Hospital, Rastak Infertility Center, Iran \\ ${ }^{3}$ Arak Infertility, Iran
}

\section{Abstract}

Para-nonylphenol is known as a toxin and an environmental pollutant that has adverse effects on the reproductive system of laboratory animals. In this review, we focus on recent studies on the effect of this pollutant on the reproductive system including testicular tissue, sperm parameters and endocrine system disorders. The reproductive system is one of the most important and extremely sensitive organs of the body that is vulnerable to oxidative stress caused by pollutants. By searching in the scientific databases of PubMed, Google Scholar, Science Direct, Springer and Web of Science related articles were extracted. As a result, all observations have confirmed that Para-nonylphenol can cause multiple damages to the male reproductive system.

Keywords: Para-nonylphenol; Reproductive system; Sperm; Testis

\section{Chemical Structure of Para-nonylphenol}

Para-nonylphenol (p-NP) is a term that can be applied to a wide range of isomeric compounds with the general formula $\mathrm{C}_{9} \mathrm{H}_{12}(\mathrm{OH}) \mathrm{C}_{6} \mathrm{H}_{4}$ (Figure-1). p-NP is an organic compound of the alkylphenol group. Alkylphenols are a small group of substances known as Xenostrogen [1]. If the position of the hydrocarbon chain linking to phenol in nonylphenol be para, it is referred to as p-NP or 4-nonyl phenol [1].

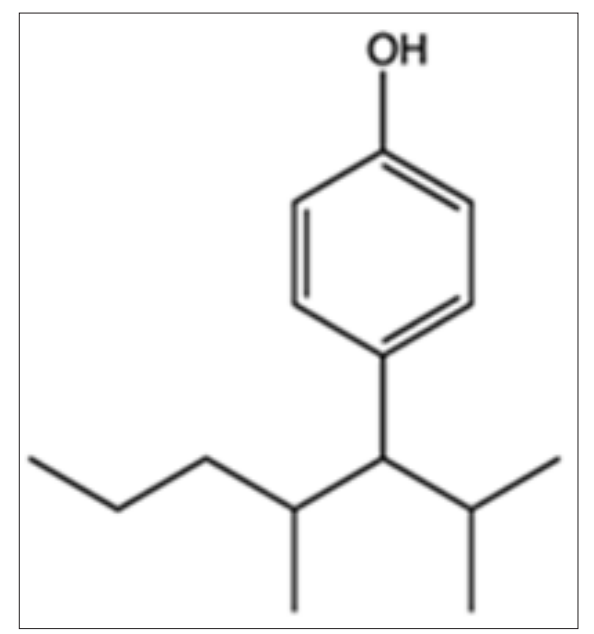

Figure 1: Chemical structure of Para-nonylphenol.

\section{Estrogenic Activity of p-NP}

p-NP has higher estrogenic activity than other alkylphenols and this effect has been observed in the male reproduction system including mice [1,2]. p-NP has been proposed to act as estrogen mimics by direct action at the estrogen receptor [3]. Estrogen was considered as a female hormone, it is also present in males and is responsible for performing some physiological functions such as maintenance of the skeletal system, normal function of testis and prostate [4]. On the other hand, p-NP can reduce the biosynthesis of testosterone by inhibiting the activity of the $17 \alpha$-HSD enzymes and the cAMP pathway of Leydig cells [5-15]. Many studies have shown that estrogenic activity disrupts sex hormones such as testosterone [6], estrogen and progesterone [7], which can decrease the chance of fertility (Table-1). 
Evaluation of Oxidative Stress and Apoptosis Induced by $\mathrm{p}-\mathrm{NP}$

p-NP can induce oxidative stress on germ cells [8] and reduces the level of antioxidant defense system [9] and also increased lipid peroxidation [10] in the testicular tissue [11]. Also, p-NP by increasing Reactive Oxygen Species (ROS) levels that cause increasing active box and the cytochrome exhaust from the mitochondria that leads to activation of the Apaf1/Caspase-9 complex. Activation of this Caspar cascade results in apoptosis [12] of germinal and Sertoli cells [10]. According to the researches presented in Table 1, it can be concluded that this pollutant increases ROS and causes apoptosis in the male reproductive system (Table-2).

Table 1: Evaluation of the adverse effect of p-NP on different species of laboratory animal (male reproductive system).

\begin{tabular}{|c|c|c|c|c|c|}
\hline \multicolumn{6}{|c|}{ Type of Response } \\
\hline Species & Dose of $p$-NP and duration of treatment & Endocrinology & Blood biochemistry & Antioxidant effect & Reference \\
\hline NMRI mice & $250 \mathrm{mg} / \mathrm{kg}-35$ day & $\downarrow \mathrm{T}$ & $\uparrow \mathrm{MDA} \uparrow \mathrm{TMDA}$ & $+\mathrm{NAC}$ & Malmir et al. [6] \\
\hline SD rat & $25,50,100 \mathrm{mg} / \mathrm{kg}-20$ day & $\downarrow \mathrm{T} \downarrow \mathrm{LH} \downarrow \mathrm{FSH}$ & $\downarrow \mathrm{AEA} \uparrow \mathrm{MDA} \&$ TMDA & & Duan et al. [2] \\
\hline SD rat & $5,20,60 \mathrm{mg} / \mathrm{kg}-20$ day & $\downarrow \mathrm{LH} \downarrow \mathrm{FSH}$ & $\downarrow \mathrm{AEA} \uparrow \mathrm{MDA} \&$ TMDA & & Duan et al. [15] \\
\hline Wistar rat & $250 \mathrm{mg} / \mathrm{kg}-90$ day & $\uparrow E \downarrow F S H$ & & +Vit. E & Momeni et al. [7] \\
\hline SD rat & $125,250 \mathrm{mg} / \mathrm{kg}-50$ day & $\downarrow T \uparrow L H \uparrow F S H$ & & & Han et al. [8] \\
\hline
\end{tabular}

NIMRI: Naval Medical Research Institute; SD: Sprague-Dawley; NAC: N- acetylcysteine; p-NP: para-nonylphenol; T: testosterone; E: Estrogen; TMDA: Tissue Malondialdehyde; MDA: Malondialdehyde; LH: Luteinizing hormone; FSH: Follicle-stimulating hormone; AEA: Antioxidant; Enzyme Activities; $\uparrow:$ Increase; $\downarrow$ : Decrease; +: positive effect on p-NP

Table 2: Evaluation of the adverse effect of p-NP on different species of laboratory animal (testicular tissue).

\begin{tabular}{|c|c|c|c|c|c|}
\hline \multicolumn{6}{|c|}{ Type of Response } \\
\hline Species & $\begin{array}{c}\text { Dose of p-NP and duration of } \\
\text { treatment }\end{array}$ & $\begin{array}{l}\text { Oxidative stress } \\
\text { and apoptosis }\end{array}$ & Stereology and histology & Reference & Reference \\
\hline NMRI mice & $250 \mathrm{mg} / \mathrm{kg}-35$ day & $\uparrow O S$ & $\begin{array}{c}\downarrow \text { Germinal Epithelium Height, } \downarrow \text { Seminiferous } \\
\text { Tubules Volume, } \uparrow \text { Interstitial tissue volume, } \\
\downarrow \text { Spermatogenic Cell, } \downarrow \text { Leydig Cell, } \uparrow \text { Edema } \uparrow \\
\text { Vacuoled, } \uparrow \text { Atrophy }\end{array}$ & $\begin{array}{l}\text { Malmir et al. } \\
{[5]}\end{array}$ & Malmir et al. [6] \\
\hline NMRI mice & $250 \mathrm{mg} / \mathrm{kg}-35$ day & $\uparrow+\mathrm{T}, \uparrow \mathrm{OS}$ & $\begin{array}{c}\text { Vacuoled, } \uparrow \text { Interstitial tissue volume, } \uparrow \text { Atrophy, } \\
\uparrow \text { Edema }\end{array}$ & $\begin{array}{l}\text { Malmir et al. } \\
{[6]}\end{array}$ & Duan et al. [2] \\
\hline SD rat & $25,50,100 \mathrm{mg} / \mathrm{kg}-20$ day & $\uparrow A p, \uparrow C C, \uparrow O S$ & $\begin{array}{c}\text { } \text { Vacuoled, } \uparrow \text { Abnormal in Spermatogonia, } \\
\uparrow \text { Primary spermatocyte cytoplasmic } \\
\text { shrinkage, } \uparrow \text { Spermatogonia abnormally, } \\
\uparrow \text { DNA fragmentation, } \uparrow \text { Degeneration with the } \\
\text { absence of spermatogenic series in the lumen }\end{array}$ & Duan et al. [2] & Duan et al. [15] \\
\hline SD rat & $5,20,60 \mathrm{mg} / \mathrm{kg}-20$ day & $\uparrow A p, \uparrow C C, \uparrow O S$ & $\begin{array}{l}\text { Tp53, Bax, Apaf- } 1 \text {, cytochrome c, cleaved- } \\
\text { caspase-3, Fas and FasL expression }\end{array}$ & $\begin{array}{l}\text { Duan et al. } \\
\text { [15] }\end{array}$ & Momeni et al. [7] \\
\hline SD rat & $100,250 \mathrm{mg} / \mathrm{kg}-63$ day & $\uparrow+\mathrm{T}, \uparrow \mathrm{CC}, \uparrow \mathrm{OS}$ & $\begin{array}{l}\downarrow \text { Reduced the frequencies of stages I-III, VII- } \\
\text { VIII, and late VIII-IX (spermiating and recently } \\
\text { spermiated tubules), respectively }\end{array}$ & $\begin{array}{l}\text { McClusky et al. } \\
2007\end{array}$ & Han et al. [8] \\
\hline SD rat & $125,250 \mathrm{mg} / \mathrm{kg}-50$ day & $\uparrow+\mathrm{T}, \uparrow \mathrm{OS}$ & $\begin{array}{c}\text { } \text { Irregular and disorder germinal cells, Shading } \\
\text { germinal cells in the lumen, } \uparrow \text { Interstitial tissue } \\
\text { volume, } \uparrow \text { Vacuoled, } \uparrow \text { Lipofuscin, } \uparrow \text { Inflation of } \\
\text { lysosomes }\end{array}$ & Han et al. [8] & \\
\hline
\end{tabular}

NIMRI: Naval Medical Research Institute; SD: Sprague-Dawley; NAC: N- acetylcysteine; p-NP: para-nonylphenol; Ap: Apoptosis; CC: Caspase; Cascade; OS: Oxidative Stress; +T: Positive-TUNEL in germinal cells; $\uparrow:$ Increase; $\downarrow$ : Decrease; + : positive effect on $\mathrm{p}-\mathrm{NP}$.

Evaluation of the Adverse Effect of p-NP on Testicular Tissue (Histological and Stereological Studies)

NP can destroy the linkage of Gap junction by reducing the expression of connexin 43 protein, causing a defect and apoptosis in spermatogenic and Sertoli cells that may be a reason for the reduction in epithelial layer $[6,13]$, as well as disruption of the blood-testicle barrier and the production of tissue edema. On the other hand, NP by stopping the B type spermatogonia in the G1 stage of mitosis because of the product of the XPB1 gene, inhibits 
the expression of cyclin 1 protein, which is one of the necessary factors for mitosis [5]. These studies listed in Table 2 demonstrates the adverse effect of this pollutant on testicular tissue.

Evaluation of the Adverse Effect of p-NP on Spermatogenesis

p-NP can induce apoptosis in germinal and Leydig cells [6] and decrease testosterone levels [5], as well as, leads to a decrease in the count and production of sperm daily [5,7]. The middle part of the sperm contains a large number of mitochondria that is responsible for movement and ROS reduces the progressive sperm motility by degenerating these mitochondria [14]. ROS by lipid peroxidation causes a decrease in membrane fluidity, damage to proteins and DNA, and eventually, abnormalities occur in sperm morphology [10]. Table 3 shows the studies of the adverse effect of p-NP on spermatogenesis.

Table 3: Evaluation of the adverse effect of p-NP on different species of laboratory animal (Spermatogenesis).

\begin{tabular}{|c|c|c|c|c|c|c|c|c|c|}
\hline \multicolumn{10}{|c|}{ Type of response } \\
\hline Species & $\begin{array}{c}\text { Dose of p-NP and } \\
\text { duration of treatment }\end{array}$ & Mot & Abn & Cou & DSP & Via & Other Parameters & Ant-E & Reference \\
\hline NMRI mice & $250 \mathrm{mg} / \mathrm{kg}$ - 35day & $\downarrow$ & $\uparrow$ & $\downarrow$ & $\downarrow$ & $\downarrow$ & $\downarrow$ Spermatogenic index, & $+\mathrm{NAC}$ & $\begin{array}{l}\text { Malmir et al. } \\
{[6]}\end{array}$ \\
\hline SD rat & $50,100 \mathrm{mg} / \mathrm{kg}-20$ day & & $\uparrow$ & & & & $\uparrow$ Rats of teratosperm, $\downarrow$ Velocity & & Duan et al. [2] \\
\hline SD rat & $60 \mathrm{mg} / \mathrm{kg}-20$ day & $\downarrow$ & $\uparrow$ & $\downarrow$ & & & $\begin{array}{l}\downarrow \text { Motile sperm density, } \downarrow \text { Density } \\
\text { of forward progression }\end{array}$ & & Duan et al. [15] \\
\hline Bufo raddei & $50,200,400 \mu \mathrm{g} / \mathrm{l} 1-3$ day & & & & & & $\begin{array}{l}\text { Nonsignificant change in Sperm } \\
\text { parameters }\end{array}$ & & Feng et al. [17] \\
\hline $\begin{array}{l}\text { Sperm of Bufo } \\
\text { raddei }\end{array}$ & $\begin{array}{c}50,200,400 \mu \mathrm{g} / \mathrm{l} 3,6,9,12, \\
25 \mathrm{~min}\end{array}$ & $\downarrow$ & & & & & $\uparrow$ Oxidative stress rate & & \\
\hline$\downarrow$ Fertilization rate & & $\begin{array}{c}\text { Feng et al. } \\
\text { [17] }\end{array}$ & & & & & & & \\
\hline Wistar rat & $250 \mathrm{mg} / \mathrm{kg}-90$ day & $\downarrow$ & & $\downarrow$ & & & $\begin{array}{c}\downarrow \text { Decrease in body and testis } \\
\text { weight }\end{array}$ & +Vit. E & $\begin{array}{l}\text { Momeni et al. } \\
\text { [7] }\end{array}$ \\
\hline SD rat & $125,250 \mathrm{mg} / \mathrm{kg}-50$ day & & & $\downarrow$ & & & $\downarrow$ spermatogenesis & & Han et al. [8] \\
\hline
\end{tabular}

NIMRI: Naval Medical Research Institute; SD: Sprague-Dawley; NAC: N- acetylcysteine; p-NP: para-nonylphenol; Mot: Motility; Abn: Abnormality; Cou: Count; DSP: Daily sperm production; Via: Vaibility; Ant-E: Antioxidant Effect; $\uparrow:$ Increase; $\downarrow$ : Decrease; +: positive effect on p-NP.

\section{Conclusion}

This study, by collecting various studies using stereological [5], histological [15], biochemical [15-18] and andrological [7] methods, showed that $\mathrm{p}$-NP at different doses and duration of treatment on laboratory animals can induce oxidative stress and apoptosis in germinal cells. This pollutant also reduces the chances of fertility by disrupting the endocrine system [2,7]. Humans are constantly exposed to p-NP through water, soil, food and vegetables. Many studies have shown that the use of antioxidants can prevent the adverse effects of oxidative stress caused by this pollutant in the male reproductive system [5].

\section{References}

1. Routledge EJ, Sumpter JP (1997) Structural features of alkylphenolic chemicals associated with strogenic activity. J Biol Chem 272(6): 32803288.

2. Duan P, Hu C, Butler HJ, Quan C, Chen W, et al. (2017) 4-Nonylphenol induces disruption of spermatogenesis associated with oxidative stress-related apoptosis by targeting p53-Bcl-2/Bax-Fas/FasL signaling. Environ Toxicol 32(3): 739-753.

3. Bindohaish G (2008) Effects of environmental pollution with alkylphenol (4-Nonyl phenol) on reproduction of tilapia, oreochromus spilurs (teleosts). Egyptian Journal of Aquatic research 34: 336-355.

4. Pettersson K, Gustafsson JA (2001) Role of estrogen receptor beta in estrogen action. Annu Rev Physiol 63: 165-192.

5. Malmir M, Faraji T, Noreini NS, Mehranjani SM (2018A) Protective antioxidant effects of n-acetylcysteine on testicular tissue and serum testosterone in paranonylphenol-treated mice (a stereological analysis). Reprod Syst Sex Disord 7(2): 2-6.

6. Malmir M, Soleimani MM, Noreini NS, Faraji T (2018B) Protective antioxidant effects of $\mathrm{N}$-acetylcysteine against impairment of spermatogenesis caused by paranonylphenol. Andrologia 50(10): e13114.

7. Momeni HR, Mehranjani SM, Abnosi MH, Mahmoodi M (2009) Effects of vitamin $\mathrm{E}$ on sperm parameters and reproductive hormones in developing rats treated with para-nonylphenol. International Journal of Reproductive BioMedicine 7(3): 111-116. 
8. Han XD, Tu ZG, Gong Y, Shen SN, Wang XY, et al. (2004) The toxic effects of nonylphenol on the reproductive system of male rats. Reproductive Toxicology 19(2): 215-221.

9. Abnosi MH, Masoomi S (2019) Para-nonylphenol toxicity induces oxidative stress and arrests the cell cycle in mesenchymal stem cells of bone marrow. Iranian Journal of Toxicology 13(3): 1-8.

10. Agarwal A (2005) Role of oxidative stress in male infertility and antioxidant supplementation. US Kidney and Urological Disease p. 122.

11. Shalaby KA, Saleh EM (2011) Ameliorative effect of honeybee propolis on the nonylphenol induced-reproductive toxicity in male albino rats. Aust J Basic Appl 5: 918-927.

12. Sayed AEDH, Kotb AM, Oda S, Kashiwada S, Mitani H (2019) Protective effect of p53 knockout on 4-nonylphenol-induced nephrotoxicity in medaka (Oryzias latipes). Chemosphere 236: 124314.

13. Lu WC, Wang AQ, Chen XL, Yang G, Lin Y, et al. (2014) 90d Exposure to nonylphenol has adverse effects on the spermatogenesis and sperm maturation of adult male rats. Biomed Environ Sci 27: 907-911.
14. Keikha L (2015) Evaluation of the protective effect of nigella sativa oil on testicular tissue and sperm parameters in adult NMRI mice treated with para-nonylphenol. SSU_Journals 23(2): 1927-1944.

15. Duan P, Hu C, Butler HJ, Quan C, Chen W, et al. (2016) Effects of 4-nonylphenol on spermatogenesis and induction of testicular apoptosis through oxidative stress-related pathways. Reprod Toxicol 62: 27-38.

16. Azizi P, Mehranjani MS (2019) The effect of green tea extract on the sperm parameters and histological changes of testis in rats exposed to para-nonylphenol. Int J Reprod Biomed 7(10): 717-726.

17. Feng $M$, Chen P, Wei X, Zhang Y, Zhang W, et al. (2011) Effect of 4-nonylphenol on the sperm dynamic parameters, morphology and fertilization rate of Bufo raddei. African Journal of Biotechnology 10(14): 2698-2707.

18. Doust KS, Noorafshan A, Dehghani F, Panjehshahin MR, Monabati A (2010) Effects of hydroalcoholic extract of Matricaria chamomilla on serum testosterone and estradiol levels, spermatozoon quality, and tail length in rat. Iranian Journal of Medical Sciences 35(2): 122-128. 